\title{
The lipopeptides pseudofactin II and surfactin effectively decrease Candida albicans adhesion and hydrophobicity
}

\author{
Piotr Biniarz • Gabriela Baranowska • \\ Joanna Feder-Kubis • \\ Anna Krasowska
}

Received: 28 February 2015/ Accepted: 18 May 2015/Published online: 29 May 2015

(C) The Author(s) 2015. This article is published with open access at Springerlink.com

\begin{abstract}
A serious problem for humans is the propensity of Candida albicans to adhere to various surfaces and its ability to form biofilms. Surfactants or biosurfactants can affect the cell surfaces of microorganisms and block their adhesion to different substrates. This study investigated adhesion of $C$. albicans strains differing in cell surface hydrophobicity (CSH) to polystyrene microplates in order to compare the ability of lipopeptide biosurfactants pseudofactin (PF II) and surfactin (SU) to prevent fungal adhesion to polystyrene. The biosurfactants decreased adhesion of tested strains by 35-90\% when microplates were conditioned before the addition of cells. A 80-90\% reduction of adhesion was observed when cells were incubated together with lipopeptides in microplates. When microplates were pre-coated with biosurfactants, PF II was less active than SU, but when cells were incubated together with biosurfactants, the activity of both compounds was similar, independent of the CSH
\end{abstract}

Electronic supplementary material The online version of this article (doi:10.1007/s10482-015-0486-3) contains supplementary material, which is available to authorized users.

P. Biniarz · G. Baranowska · A. Krasowska $(\bowtie)$ Faculty of Biotechnology, University of Wrocław, ul. Fryderyka Joliot-Curie 14a, 50-383 Wrocław, Poland e-mail: anna.krasowska@uni.wroc.pl

\section{J. Feder-Kubis}

Faculty of Chemistry, Wrocław University of

Technology, Wybrzeże Wyspiańskiego 27,

50-370 Wrocław, Poland of strains. When cells were preincubated with lipopeptides and then the compounds were washed out, the adhesion of hydrophobic strains increased two times in comparison to control samples. This suggests irreversible changes in the cell wall after the treatment with biosurfactants. CSH of hydrophobic strains decreased only by $20-60 \%$ after incubation with biosurfactants while adhesion decreased by $80-90 \%$; the changes in cell adhesion can be thus only partially explained through the modification of CSH. Preincubation of $C$. albicans with biosurfactants caused extraction of cell wall proteins with molecular mass in the range of $10-40 \mathrm{kDa}$, which is one possible mechanism of action of the tested lipopeptides.

Keywords Candida albicans $\cdot$ Lipopeptides · Biosurfactants · Adhesion · CSH

\section{Introduction}

Candida albicans is responsible for fungaemia, especially in immunocompromised patients. Cell features that cause mycoses encompass, e.g., adhesion, secretion of hydrolytic enzymes, filamentation and hydrophobicity (Verstrepen and Klis 2006). Understanding how C. albicans morphogenesis modulates the molecular composition of the fungal cell surface and interactions with biotic and abiotic surfaces is important, but still unclear. 
The microbial adhesion results from specific interactions between cell surface structures and the surface of the substrate, or from non-specific interaction forces, including Brownian movement, van der Waals attraction, gravitational forces and surface electrostatic charges. One of the important factors is the hydrophobicity of cell surface (Krasowska and Sigler 2014).

Cell surface hydrophobicity (CSH) is connected with adhesion and pathogenic processes of $C$. albicans. Hydrophobic cells are more adherent than hydrophilic ones to epithelial and endothelial tissues as well as to abiotic surfaces (Glee et al. 2001; Hazen 2004).

Hydrophobicity of $C$. albicans cells alters in response to changes in environmental conditions (e.g. temperature, composition of medium) and growth phases (Hazen et al. 2001) and can be switched between hydrophilic and hydrophobic phenotypes (Masuoka and Hazen 1997). Hydrophilic cells have an elongated acid-labile mannan fraction in the cell wall and the length of this structure affects the folding of cell wall fibrils (Masuoka and Hazen 1999).

Chaffin (2008) supposed that Csh1 protein influences the acid-labile mannan composition, because of differences between hydrophobic and hydrophilic cells in mannan fractions. Mannoproteins can therefore be potential targets for new antifungal drugs (Gow et al. 1999).

Biosurfactants such as lipopeptides are particularly interesting as antifungals because of their high surface activity and antibiotic potential. Several natural lipopeptides, e.g. echinocandins, block specific enzymatic reactions in the synthesis of cell wall components (e.g. $\beta$-1,3-glucan or chitin). Lipopeptides such as surfacin (SU), iturin and bafilomycin disturb the plasma membrane (Makovitzki et al. 2006). The adsorption of biosurfactant molecules on a surface was found to change its hydrophobicity, which might cause changes in the adhesion processes (Zhong et al. 2008; Singh et al. 2013).

Previously, we described the antiadhesive activity of the lipopeptide pseudofactin II (PF II), produced by Pseudomonas fluorescens BD5 (Janek et al. 2010) against several uropathogenic bacteria and $C$. albicans, and did not detect a significant impact on $C$. albicans growth (Janek et al. 2012).

PF II and SU are both cyclic lipopeptides. In the PF II molecule a palmitic acid is connected to hydrophilic "head" of eight uncharged amino acids (Janek et al. 2010), whereas SU is a lipoheptapeptide linked to a $\beta$ - hydroxyl fatty acid. Commercially available SU (Sigma-Aldrich) is a mixture of congeners that differ in the length of the carbon chain $\left(\mathrm{C}_{12}-\mathrm{C}_{16}\right)$. Moreover $\mathrm{SU}$ is negatively-charged because of Asp and Glu amino acids within the molecule (Raaijmakers et al. 2010). These differences cause a variations in the biological activity of lipopeptides e.g. disruption of plasma membrane by SU.

In this work we compared the action of PF II and SU on C. albicans strains that differ in $\mathrm{CSH}$. We examined the influence of lipopeptides on the viability and adhesion of $C$. albicans on polystyrene. We also checked the impact of the biosurfactants on CSH of $C$. albicans. Our results suggest differences in the mechanisms of action between PF II and SU. Micelles of PF II and SU cause irreversible changes in the cell wall of hydrophobic strains of $C$. albicans but a decrease in adhesion could be explained only partially by the influence of lipopeptides on CSH. Moreover, the biosurfactants appeared to be able to extract some cell surface-associated proteins from $C$. albicans cell wall (CWP), which is demonstrated for the first time in this work.

\section{Materials and methods}

Microorganisms and culture conditions

Biosurfactant-producing strain P. fluorescens BD5, obtained from freshwater from Arctic Archipelago of Svalbard, was cultivated in LB medium as described earlier (Janek et al. 2010). C. albicans strains (Table 1) were a generous gift from D. Sanglard (Lausanne, Switzerland) and were cultivated in $5 \mathrm{ml}$ YPG broth containing $10 \mathrm{~g} / \mathrm{l}$ bactopeptone (Difco, USA), $10 \mathrm{~g} / \mathrm{l}$ yeast extract (Difco, USA), and $20 \mathrm{~g} / \mathrm{l}$ glucose (Bioshop, Canada). Candida cultures were incubated at $28{ }^{\circ} \mathrm{C}$ for $24 \mathrm{~h}$ without agitation and then stored at $4{ }^{\circ} \mathrm{C}$ for a maximum of 2 weeks. All experiments were carried out on fresh C. albicans pre-cultures $(4.85 \mathrm{ml}$ of YPG inoculated with $150 \mu \mathrm{l}$ of $C$. albicans culture and incubated for $24 \mathrm{~h}$ at $28^{\circ} \mathrm{C}$ ). Before conducting the experiments C. albicans cells were centrifuged twice $(1000 \times g)$ for washing out the culturing medium and resuspended in PBS $\mathrm{pH}=7.4\left(8 \mathrm{~g} / \mathrm{l} \mathrm{NaCl}, 1.4 \mathrm{~g} / 1 \mathrm{Na}_{2} \mathrm{HPO}_{4}\right.$, $\left.0.25 \mathrm{~g} / 1 \mathrm{KH}_{2} \mathrm{PO}_{4}, 0.2 \mathrm{~g} / \mathrm{K} \mathrm{KCl}\right)$ or phosphate buffer (PB; $16.9 \mathrm{~g} / 1 \mathrm{~K}_{2} \mathrm{HPO}_{4}, 7.3 \mathrm{~g} / 1 \mathrm{KH}_{2} \mathrm{PO}_{4}$ ). 
Table 1 Candida albicans strains used in work

\begin{tabular}{|c|c|c|}
\hline Strain & Genotype & Reference \\
\hline SC5314 & Clinical isolate & (Gillum et al. 1984) \\
\hline CAF2-1 & Aura3::imm434/URA3 & (Fonzi and Irwin 1993) \\
\hline CAF4-2 & $\Delta$ ura3::imm434/ $\Delta$ ura3::imm434 & (Fonzi and Irwin 1993) \\
\hline DSY653 & $\Delta c d r 2::$ hisG/ $\Delta$ cdr2::hisG-URA3-hisG & (Sanglard et al. 1997) \\
\hline DSY1050 & $\begin{array}{l}\Delta c d r 1: \text { hisG/ } \Delta c d r 1:: \text { hisG } \Delta c d r 2:: \text { hisG/ } \Delta c d r 2:: \text { hisG } \\
\quad \Delta \text { mdr1::hisG-URA3-hisG/ } \Delta \text { mdr1::hisG }\end{array}$ & (Mukherjee and Chandra 2003) \\
\hline
\end{tabular}

Fig. 1 Cell surface hydrophobicity (CSH) of $C$. albicans strains cultivated in YPG medium supplemented with $0.2 \%$ glucose (black bars) or $2 \%$ glucose (grey bars). Differences in $\mathrm{CSH}$ between strains cultivated in different media were analyzed using modified paired Student $t$ test $* P<0.05, * * P<0.001$

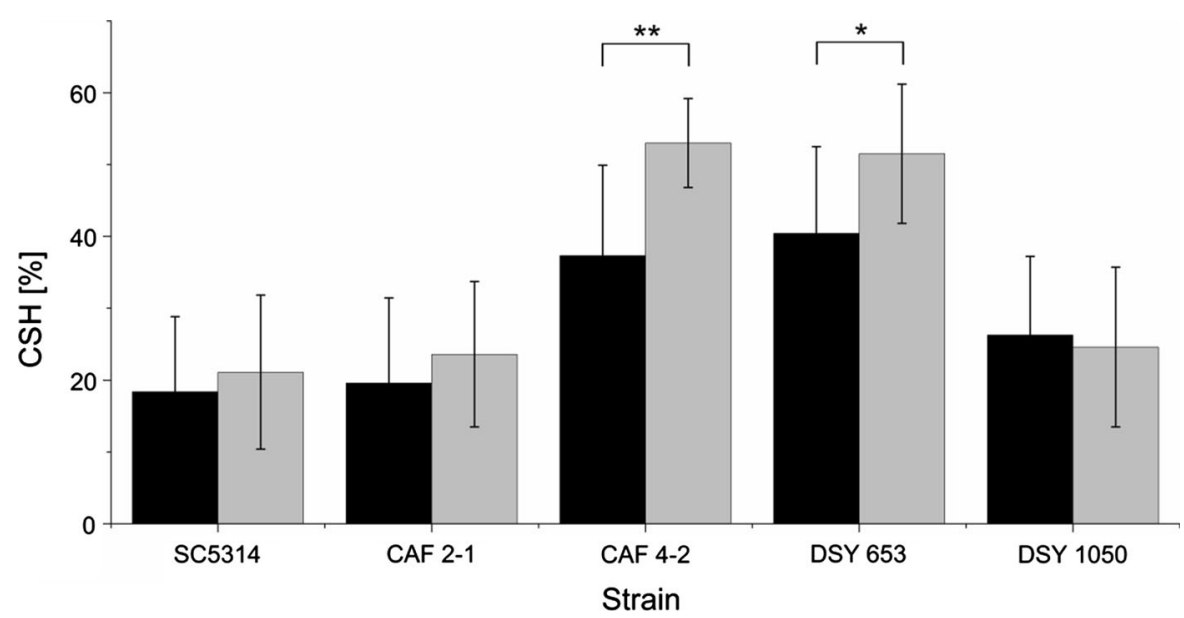

Production, isolation and purification of pseudofactin II (PFII)

For the production of PFII, P. fluorescens BD5 was cultivated in mineral salt medium (MSM) containing $7 \mathrm{~g} / 1 \mathrm{~K}_{2} \mathrm{HPO}_{4}, 2 \mathrm{~g} / 1 \mathrm{KH}_{2} \mathrm{PO}_{4}, 1 \mathrm{~g} / \mathrm{l}\left(\mathrm{NH}_{4}\right)_{2} \mathrm{SO}_{4}, 0.5 \mathrm{~g} / \mathrm{l}$ sodium citrate $\times 2 \mathrm{H}_{2} \mathrm{O}$, and $0.1 \mathrm{~g} / 1 \mathrm{MgSO}_{4} \times 7 \mathrm{H}_{2} \mathrm{O}$ supplemented with $20 \mathrm{~g} / \mathrm{l}$ glucose at $28{ }^{\circ} \mathrm{C}$ without agitation as described earlier (Janek et al. 2010). Briefly, 0.51 of MSM was inoculated with $5 \mathrm{ml}$ of $P$. fluorescens BD5 culture in LB $\left(24 \mathrm{~h}, 28{ }^{\circ} \mathrm{C}\right)$ and incubated for 1 week at $28{ }^{\circ} \mathrm{C}$ without agitation. Cellfree supernatant was afterwards extracted three times with ethyl acetate. The solvent was evaporated under vacuum and crude extract was dissolved in methanol and purified by RP-HPLC (Janek et al. 2010).

Biosurfactant concentrations

Biosurfactants were tested in the final concentrations of 0.035 or $0.1 \mathrm{mg} / \mathrm{ml}$ for PFII and 0.005 or $0.015 \mathrm{mg}$ / $\mathrm{ml}$ for SU. These concentrations were chosen to test the influence of biosurfactant monomers $(\sim 0.5 \times \mathrm{CMC})$ and micelles $(\sim 1.5 \times \mathrm{CMC})$. PFII was extracted and purified as described above. SU was manufactured by Sigma-Aldrich (USA). Biosurfactant stock solutions were dissolved in PBS and stored at $-20{ }^{\circ} \mathrm{C}$.

Antifungal activity of biosurfactants

The antifungal activity of biosurfactants was tested in 96-well flat-bottom polystyrene microplates (Sarstedt, Germany). We added $50 \mu \mathrm{l}$ of double strength YPG and $50 \mu \mathrm{l}$ of biosurfactant solution in PBS to each well or PBS to control wells. Every well was afterwards inoculated with overnight Candida culture in YPG to reach the initial optical density at $600 \mathrm{~nm}\left(\mathrm{OD}_{600}\right)$ of 0.01 . The microplates were then incubated for $24 \mathrm{~h}$ at $30^{\circ} \mathrm{C}$. After incubation the $\mathrm{OD}_{600}$ was measured with UMV 340 microplate reader (Asys Hitech, Austria). Antifungal activity of biosurfactants is expressed as a 
Fig. 2 Growth of $C$. albicans strains in the presence of $0.035 \mathrm{mg} / \mathrm{ml}$ (grey bars) and $0.1 \mathrm{mg} / \mathrm{ml}$ (inverse-hatched bars) PF II in PBS or $0.005 \mathrm{mg} / \mathrm{ml}$ (hatched bars) and $0.015 \mathrm{mg} / \mathrm{ml}$ (white bars) $\mathrm{SU}$ in PBS, compared to control (black bars)

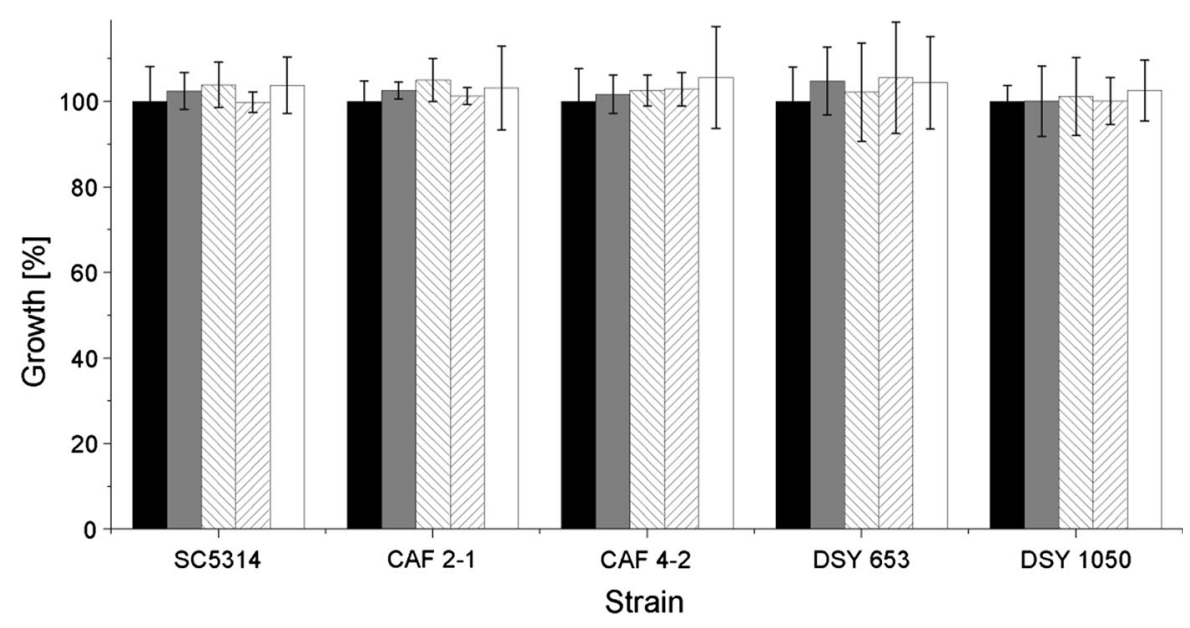

growth inhibition in comparison to samples without biosurfactants $(100 \%)$ :

Growth inhibition $(\%)=100 \times\left[1-\frac{O D_{T}}{O D_{C}}\right]$

where $\mathrm{OD}_{\mathrm{T}}$ is the $\mathrm{OD}_{600}$ of wells containing biosurfactants in PBS and $\mathrm{OD}_{\mathrm{C}}$ is the $\mathrm{OD}_{600}$ of control samples (wells without biosurfactants).

\section{Cell surface hydrophobicity (CSH)}

For determining the effect of biosurfactants on $C$. albicans $\mathrm{CSH}$, cell suspensions in PB were transferred to Eppendorf test tubes and PFII or SU stock solutions in PBS were added to reach the biosurfactant final concentrations. The same amount of PBS was added to the control samples. Suspensions were incubated for $2 \mathrm{~h}$ at $37{ }^{\circ} \mathrm{C}$ with agitation $(300 \mathrm{rpm})$ and then diluted to an $\mathrm{OD}_{600}$ of 0.5 . The MATH (microbial adhesion to hydrocarbon) was used to evaluate the $\mathrm{CSH}$ of Candida cells (Coimbra et al. 2009). Briefly, $2 \mathrm{ml}$ of the cell suspension in PB were moved to a glass tube $(100 \times 15.5 \mathrm{~mm})$ and $100 \mu \mathrm{l}$ of hexadecane $\mathrm{w}$ added. The samples were then vortex-shaken for $3 \mathrm{~min}$ and the phases were allowed to separate for $1 \mathrm{~h}$. The $\mathrm{OD}_{600}$ of the aqueous phase was measured and $\mathrm{CSH}$, defined as percentage of cells adhering to hexadecane, was calculated as follows:

$\operatorname{CSH}(\%)=100 \times\left[1-\frac{O D_{600}}{0.5}\right]$

where $\mathrm{OD}_{600}$ is the optical density of the aqueous phase at $600 \mathrm{~nm}$. In modified trials, biosurfactants were washed out (centrifugation $1000 \times g$ ) with $\mathrm{PB}$ before diluting cell suspensions to an OD of 0.5 and measuring $\mathrm{CSH}$.
Fig. 3 Adhesion of $C$. albicans strains to polystyrene microplates pretreated with $0.035 \mathrm{mg} / \mathrm{ml}$ (grey bars) and $0.1 \mathrm{mg} / \mathrm{ml}$ (inverse-hatched bars) PF II in PBS or $0.005 \mathrm{mg} / \mathrm{ml}$ (hatched bars) and $0.015 \mathrm{mg} / \mathrm{ml}$ (white bars)

$\mathrm{SU}$ in PBS, compared to control adhesion (black bars). Statistical analysis was performed with modified paired $t$ test $* P<0.05, * * P<0.01$, $* * * P<0.001$

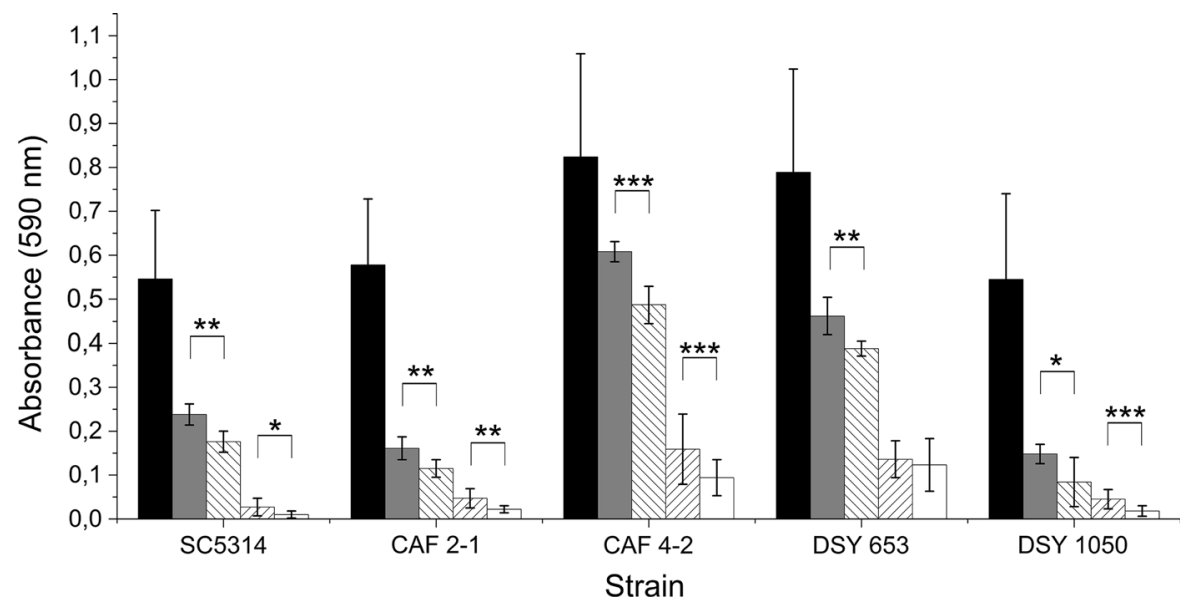




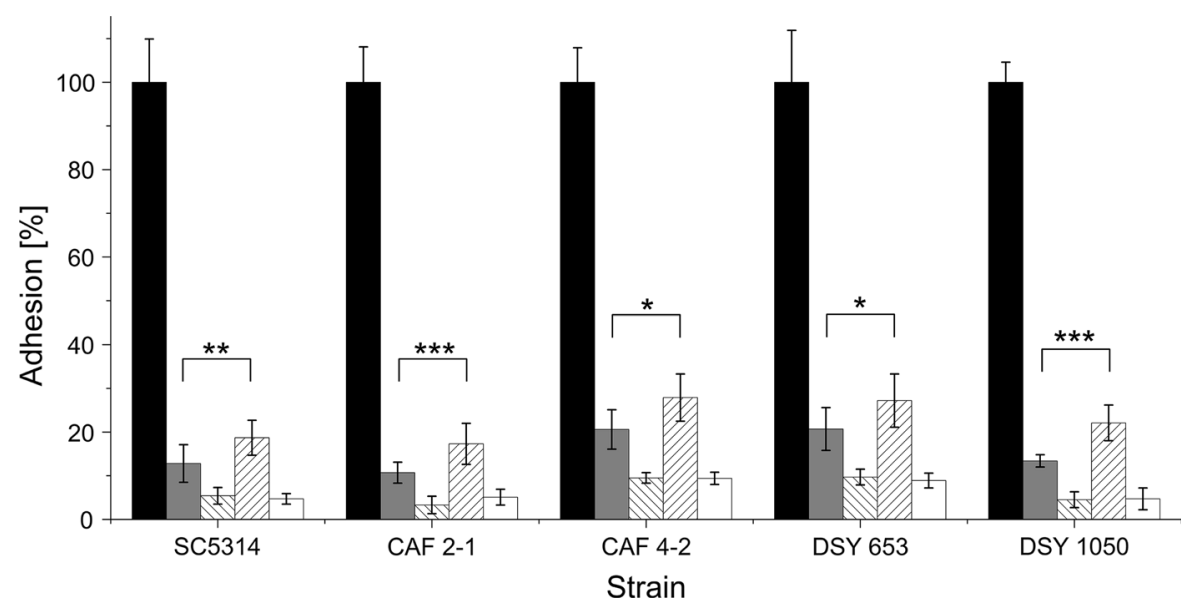

Fig. 4 Adhesion of $C$. albicans strains in the presence of $0.035 \mathrm{mg} / \mathrm{ml}$ (grey bars) and $0.1 \mathrm{mg} / \mathrm{ml}$ (inverse hatched bars) PF II in PBS or $0.005 \mathrm{mg} / \mathrm{ml}$ (hatched bars) and $0.015 \mathrm{mg} / \mathrm{ml}$ (white bars) SU in PBS, compared to adhesion of strains

incubated in PBS (black bars) after 2-h incubation in $37^{\circ} \mathrm{C}$. Statistical analysis was performed with a modified paired $t$ test $* P<0.05, * * P<0.01, * * * P<0.001$
Fig. 5 Adhesion of $C$. albicans cells preincubated with $0.035 \mathrm{mg} / \mathrm{ml}$ (grey bars) and $0.1 \mathrm{mg} / \mathrm{ml}$ (inverse hatched bars) PF II in PBS or $0.005 \mathrm{mg} / \mathrm{ml}$ (hatched bars) and $0.015 \mathrm{mg} / \mathrm{ml}$ (white bars) $\mathrm{SU}$ in PBS, compared to adhesion of strains preincubated in PBS (black bars). Two different assays were performed:

biosurfactants were present in solution during adhesion test (a) or were washed out after $2 \mathrm{~h}$ of preincubation prior to adhesion test (b). Statistical analysis was performed by modified paired $t$ test $* P<0.05$, ** $P<0.01$, *** $P<0.001$
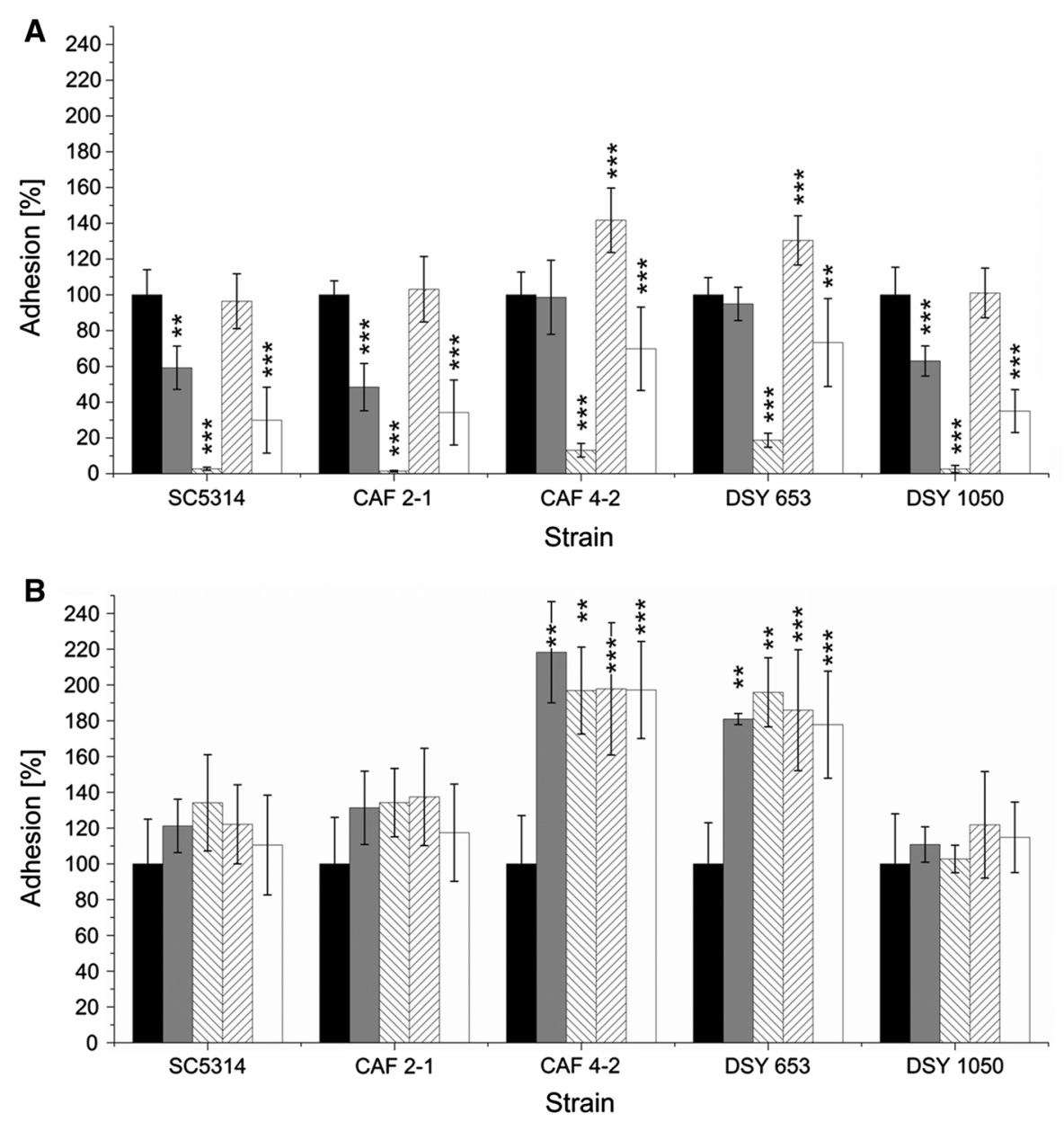
Adhesion of Candida albicans to polystyrene

PF II and SU were tested as C. albicans adhesioninhibiting agents in flat-bottom 96-well polystyrene microplates (Sarstedt, Germany) in three different assays. In pre-adhesion assay, microplate wells were preincubated with $100 \mu \mathrm{l}$ of biosurfactant solutions in PBS for $2 \mathrm{~h}$ at $37^{\circ} \mathrm{C}$ with agitation (300 rpm). PBS buffer was used as a positive control. Subsequently, wells were washed two times with PBS. C. albicans suspensions in PBS were diluted to give an $\mathrm{OD}_{600}$ of 0.6. The highest adhesion of $C$. albicans strains to polystyrene was observed at this OD (Janek et al. 2012). $100 \mu \mathrm{l}$ of Candida suspensions were added to wells and incubated for $2 \mathrm{~h}$ at $37^{\circ} \mathrm{C}$ with agitation (300 rpm). Then supernatants were removed and wells were washed two times with PBS to remove nonadherent cells. Adherent cells were stained with $0.1 \%$ crystal violet for $5 \mathrm{~min}$ and then wells were washed three times with PBS. The dye was released by $200 \mu \mathrm{l}$ of $0.05 \mathrm{M} \mathrm{HCl}$ with $1 \%$ SDS in isopropanol and the absorbance at $590 \mathrm{~nm}\left(\mathrm{Abs}_{590}\right)$ was read off with Asys UMV 340 microplate reader (Asys Hitech, Austria). Cell adhesion was expressed as the $\mathrm{Abs}_{590}$ or as the percentage of $\mathrm{Abs}_{590}$ of control samples (100\%):

Adhesion $(\%)=100 \times\left[1-\frac{A b s_{T}}{A b s_{C}}\right]$

where $\mathrm{Abs}_{\mathrm{t}}$ is the $\mathrm{Abs}_{590}$ of wells pretreated with biosurfactants and $\mathrm{Abs}_{\mathrm{c}}$ is the $\mathrm{Abs}_{590}$ of control wells (pretreated with PBS only). In addition, we tested $C$. albicans adhesion to microplates in the presence of biosurfactants. Briefly, we added biosurfactants to Candida suspensions in PBS to reach final concentrations and the $\mathrm{OD}_{600}$ of 0.6. The same amount of PBS was added to the control samples. Then, $100 \mu \mathrm{l}$ of suspensions were added to microplate wells and incubated for $2 \mathrm{~h}$ at $37{ }^{\circ} \mathrm{C}$ with agitation (300 rpm). The microplates were washed, stained and read as described before. We also investigated the influence of preincubation of $C$. albicans strains with biosurfactants on their adhesion abilities. In brief, Candida cell suspensions in PBS were transferred to Eppendorf test tubes and biosurfactants were added to the desired final concentrations. The same amount of PBS was added to the control samples. Suspensions were incubated for $2 \mathrm{~h}$ at $37{ }^{\circ} \mathrm{C}$ with agitation $(300 \mathrm{rpm})$ and diluted to an $\mathrm{OD}_{600}$ of 0.6 . Then, $100 \mu \mathrm{l}$ of suspensions were added to microplate wells and incubated for $2 \mathrm{~h}$ at $37{ }^{\circ} \mathrm{C}$ with agitation (300 rpm). Microplates were washed, stained and read as described before. In modified trials, biosurfactants were washed out (centrifugation $1000 \times g$ ) with PBS before diluting cell suspensions to an $\mathrm{OD}_{600}$ of 0.6 and conducting the adhesion assay.

Extraction of cell-wall associated proteins (CWP) by biosurfactants

We also tested if the addition of biosurfactants can cause extraction of proteins from the $C$. albicans cell surface. To conduct the experiment, Candida cell suspensions in PBS were transferred to Eppendorf test tubes and biosurfactants were added to the final concentrations. The same amount of PBS was added to the control samples. Suspensions were incubated for $2 \mathrm{~h}$ at $37{ }^{\circ} \mathrm{C}$ with agitation (300 rpm). Then cells were removed by centrifugation $(1000 \times g)$ and filtration $(0.2 \mu \mathrm{m})$. Proteins in supernatants were concentrated with Amicon Ultra $0.5 \mathrm{~mL} 3 \mathrm{kDa}$ centrifugal filters (Millipore, USA). Concentrated samples were mixed with $\times 6$ denaturation buffer $(150 \mathrm{mM}$ Tris; $0.6 \mathrm{M}$ EDTA; $12 \%$ SDS; $60 \mathrm{mM}$ DTT), heated at $95{ }^{\circ} \mathrm{C}$ for $5 \mathrm{~min}$ and loaded onto $15 \%$ polyacrylamide gel. Silver-stained gels were photographed with ChemiDoc System (Bio-Rad, USA).

\section{Fluorescence microscopy}

Candida cell suspensions in PBS were transferred to Eppendorf test tubes and biosurfactants were added to the final concentrations. The same amount of PBS was added to the control samples. SDS was added to the final concentration of $1 \%$ and served as positivecontrol samples. Suspensions were incubated for $2 \mathrm{~h}$ at $37{ }^{\circ} \mathrm{C}$ with agitation (300 rpm) as described above. Then cells were centrifuged twice $(1000 \times g)$ and resuspended in PBS buffer. PI from stock solution (Bioshop, Canada) was added to the final concentration of $6 \mu \mathrm{M}$ and suspensions were incubated for $5 \mathrm{~min}$ at room temperature. Next, Candida cells were pelleted and washed twice with PBS. $4 \mu \mathrm{l}$ of Candida pellets were viewed with Zeiss Axio Imager A2 fluorescence microscope. 
Fig. 6 Cell surface hydrophobicity (CSH) of $C$. albicans strains pretreated with $0.035 \mathrm{mg} / \mathrm{ml}$ (grey bars) and $0.1 \mathrm{mg} / \mathrm{ml}$ (inverse hatched bars) PF II in PBS or $0.005 \mathrm{mg} / \mathrm{ml}$ (hatched bars) and $0.015 \mathrm{mg} / \mathrm{ml}$ (white bars) SU in PBS, compared to control samples (black bars). The CSH was measured in the presence of biosurfactants in Candida suspension (a) or after rinsing out the surfaceactive compounds (b). Statistical analysis was performed by modified paired $t$ test $* P<0.05$, $* * P<0.01, * * * P<0.001$
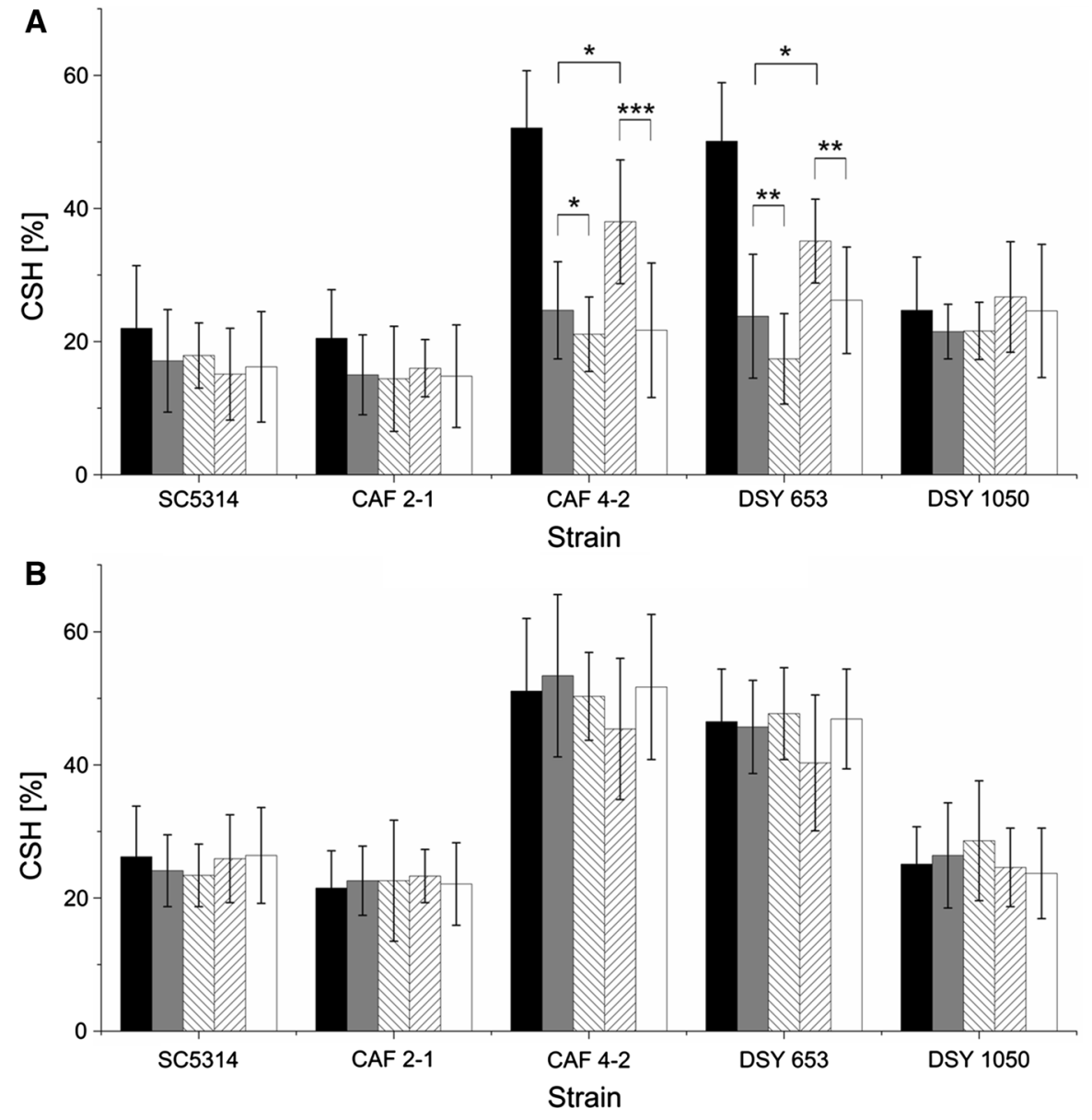

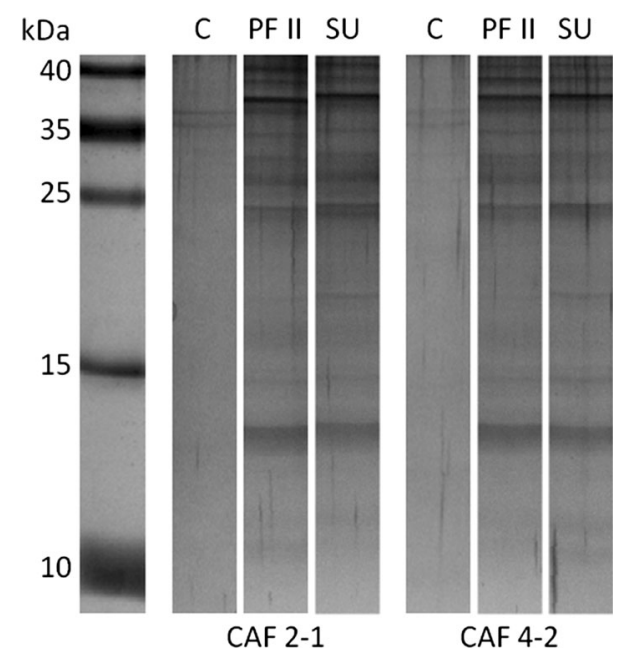

Fig. 7 SDS-PAGE electrophoresis of proteins obtained after incubation of $C$. albicans cells with $0.1 \mathrm{mg} / \mathrm{ml} \mathrm{PF}$ II or $0.015 \mathrm{mg} / \mathrm{ml} \mathrm{SU}$ in comparison to control samples (C)

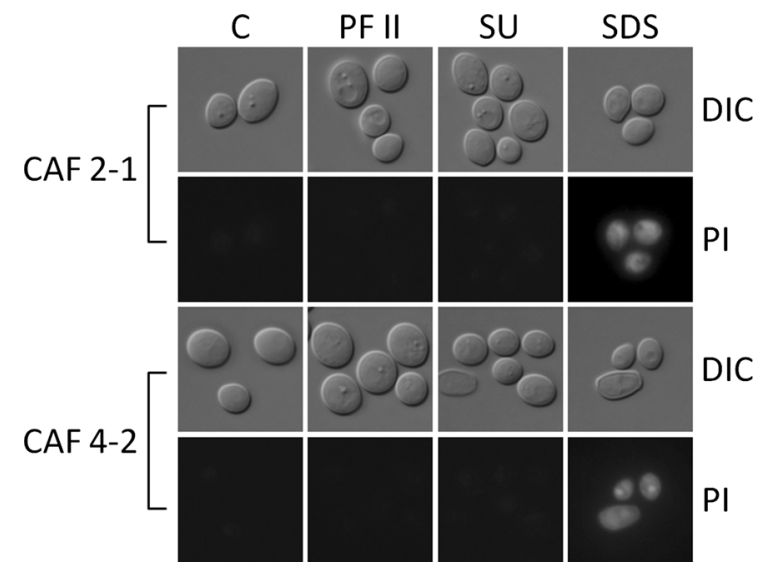

Fig. 8 Propidium iodine (PI) fluorescence and differential interference contrast (DIC) microphotographs of $C$. albicans cells incubated with $0.1 \mathrm{mg} / \mathrm{ml}$ PF II or $0.015 \mathrm{mg} / \mathrm{ml} \mathrm{SU}$ in comparison with control samples (C) and $1 \%$ SDS as positive controls 
Statistical analysis

All described assays were carried out at least three times in three replicates. Statistical analyses were performed using paired $t$ test with Bonferroni correction. $P$ values of $<0.05$ were considered significant.

\section{Results and discussion}

C. albicans can use various carbon sources: glucose, galactose, fructose or hydrocarbons. Carbon sources at different concentrations promote changes in the structure of cell wall (McCourtie and Douglas 1981); thus increasing sugar concentration in the medium from 50 to $500 \mathrm{mM}$ resulted in the production of an outer fibrillar-floccular layer of mannoproteins and also a linear increase of adherence to acrylic surfaces (McCourtie and Douglas 1981). Different culture conditions have therefore an impact on surface properties of Candida cells (Hobden et al. 1995).

In our collection of $C$. albicans strains (Table 1), CAF4-2 and DSY653 were more hydrophobic than other strains $(P<0.001)$ (Fig. 1).

A change in glucose concentration in the medium from 2 to $0.2 \%$ decreased CSH but only in the case of two strains with the highest hydrophobicity (Fig. 1). These results suggest differences in cell wall composition and metabolism of URA3 mutants as reported earlier (Bain et al. 2001). Our results also indicate an impact of the site of integration of URA3 in $C$. albicans genome on changes in surface properties. Strains DSY653 and DSY1050 that vary in the site of integration of URA3 differ in some aspects such as CSH (Fig. 1).

Microbial surfactants often have antimicrobial properties but knowledge about mechanisms of their action is scarce. A few studies have shown that rhamnolipids increase the membrane permeability and alter its barrier function, causing cell damage (Sotirova et al. 2008). Lipopeptides such as SU, iturin or lichenisyn form ion-conducting membrane channels (Pueyo et al. 2009; Bensaci et al. 2011). In contrast to many other lipopeptides (Peypoux et al. 1999; Grangemard et al. 2001), PF II showed much weaker antimicrobial activity against bacterial and $C$. albicans strains (Janek et al. 2012). Also SU in tested concentrations exhibited no antifungal activity (Fig. 2). PF II was found to possess an antiadhesive, concentration-dependent activity against bacteria and yeast. The highest reduction of adhesion (80-99 \%) was observed for C. albicans wild-type strain SC5314 (Janek et al. 2012). PF II was effective above the critical micelle concentration $(0.072 \mathrm{mg} / \mathrm{ml})$ and the adhesion was thus inhibited more strongly by micelles than by monomers (Janek et al. 2012). The microbial adhesion depends on the composition of the outer cell layer and is connected with hydrophobic/hydrophilic and ionic properties of the cell as well as with the properties of the polystyrene surface of microplates used in experiments (Neu 1996). PF II, due to its nonionic character, can probably coat positively or negatively charged surfaces, changing their properties.

We studied the adhesion of $C$. albicans to polystyrene microplates in a number of different experiments to compare the ability of PF II and SU to prevent fungal adhesion to abiotic surfaces. It is obvious that strains CAF4-2 and DSY653 have modified surface properties, but the nature of these changes is not clear (Bain et al. 2001).

We observed a decrease in adhesion of all tested $C$. albicans strains when the microplates were pretreated with PF II before the addition of the microorganisms (pre-adhesion assay) (Fig. 3). PF II was more active in concentrations higher than CMC $(0.1 \mathrm{mg} / \mathrm{ml})$ (Fig. 3). We observed a similar concentration-dependent effect for SU used as a standard lipopeptide biosurfactant, which decreased the adhesion even more than PF II $(P<0.001)$ (Fig. 3). CAF4-2 and DSY653 adhered to the polystyrene microplate surface better than the other strains $(P<0.01)$ and were able to adhere to a surface pretreated with lipopeptides more strongly than other strains $(P<0.001)$ (Fig. 3).

Surprisingly, when cells and lipopeptides were incubated together for $2 \mathrm{~h}$ in the polystyrene $\mathrm{mi}$ croplate, the adhesion was blocked even more strongly (Fig. 4). Both PF II and SU micelles reduced $C$. albicans adhesion by $\sim 90 \%$. As for biosurfactant monomers, the action of lipopeptides was different. In this case, PF II was found to be a better antiadhesive agent than SU (Fig. 4). The antiadhesive activity of SU was similar to the situation when it coated the microplate before the addition of Candida suspension (cf. Figs. 3, 4). PF II was less active than SU in the case of hydrophobic strains when the microplate was coated before the addition of cells but when hydrophobic cells were incubated together with PF II, their adhesion decreased like in hydrophilic strains 
(Figs. 3, 4). These results suggest differences in the mechanisms of action between PF II and SU, e.g. interactions between cell surface and/or polystyrene.

Interesting results were observed when the cells were preincubated with biosurfactants and the adhesion of coated and non-coated cells to polystyrene microplate was investigated (Fig. 5). When present in the solution (Fig. 5a), lipopeptides act as strong antiadhesives in micellar concentrations. PF II monomers reduced the adhesion of hydrophilic strains approximately two times and did not alter adhesion of hydrophobic strains CAF4-2 and DSY653 (Fig. 5a). Monomers of SU did not change adhesion of hydrophilic strains and increased it in the case of hydrophobic strains (Fig. 5a). During incubation of Candida cells with the biosurfactants, the predisposition of cells to adhesion changed and was different from the case when the microplate was pre-coated with PF II or SU (Figs. 3, 5). However, micelles of PF II decreased adhesion to the same low level (10-20\%) as in experiments with a 2-h adhesion of cells coated with PF II (Fig. 4). When the biosurfactants were washed out before conducting the experiment, the adhesion of hydrophilic strains was comparable to control samples whereas for hydrophobic strains adhesion increased approximately two times (Fig. 5b). This result suggests irreversible changes in the cell wall of hydrophobic strains of $C$. albicans caused by micelles of PF II and SU after a 2-h incubation.

The microbial ability of adhering to different surfaces is connected with $\mathrm{CSH}$, hence our intention was to investigate the influence of lipopeptides on Candida CSH. Biosurfactants can change CSH due to adsorbing to the cell surface (Kaczorek et al. 2013), like rhamnolipids which strongly adsorbed on the cell surface of yeast (Kaczorek et al. 2008).

After a 2-h incubation with PF II or SU, CSH of $C$. albicans CAF4-2 and DSY653 significantly decreased and this effect was concentration-dependent. Monomers of PF II influenced CAF4-2 and DSY653 more strongly than monomers of SU. Other tested strains seemed resistant to the influence of biosurfactants (Fig. 6a). On the other hand, when biosurfactants were washed out, CSH level of hydrophobic cells recovered (Fig. 6b). In this assay the time of incubation with biosurfactants was $2 \mathrm{~h}$ and these conditions can be compared to experiments with adhesion of cells treated with biosurfactants (Fig. 4). CSH of hydrophobic strains decreased only by $20-60 \%$ (Fig. 6) while adhesion decreased by $80-90 \%$ (Fig. 4). Also the potential irreversible changes in the cell surface of $C$. albicans caused by lipopeptides have an impact on adhesion but not on CSH of hydrophobic strains (cf. Figs. 5, 6). This result suggests that decrease in cell adhesion by lipopeptides can be only partially explained by the modification of $\mathrm{CSH}$ and should be considered only in the case of hydrophobic strains CAF4-2 and DSY653.

One of the mechanisms of action of lipopeptides on C. albicans cells could be a decrease in the level of some compounds (e.g. chitin, $\beta$-1,3-glucan) in the cell wall (Bizerra et al. 2011). Some protocols for the fractionation of fungal cell walls include treatment with synthetic surfactants (Pitarch et al. 2002; Klis et al. 2007). Therefore, we isolated several proteins from cellfree supernatants after preincubation of $C$. albicans cells with biosurfactants and visualized them on silverstained polyacrylamide gels (Fig. 7). We determined molecular masses of these proteins after SDS-PAGE electrophoresis to be in the range from $\sim 10$ to $40 \mathrm{kDa}$ and observed no differences between the action of PF II and SU or between hydrophobic and hydrophilic strains (Fig. 7). Simultaneously, PAS (Periodic acid-Schiff) staining for glycoproteins showed no bands on the gels (data not shown). Therefore, partial disruption of cell wall and extraction of cell surface-associated proteins can be the possible mechanism of the action of lipopeptide biosurfactants on C. albicans.

To exclude the possibility of contamination of cellfree supernatants (Fig. 7) with cytoplasmic proteins, we analyzed viability and membrane permeability of Candida cells with fluorescence microscopy (Fig. 8). The lack of propidium iodine (PI) fluorescence in control samples and cells incubated with lipopeptides indicate that cells were viable and membranes permeability was undisturbed (Fig. 8), which also confirms viability results shown earlier (Fig. 2). In contrast, cells treated with $1 \%$ SDS showed significant fluorescence of dead cells.

Acknowledgments This work was supported by Wroclaw Centre of Biotechnology, programme The Leading National Research Centre (KNOW) for years 2014-2018 and by the University of Wroclaw, Faculty of Biotechnology grant 2342/M/WB/14. 
Open Access This article is distributed under the terms of the Creative Commons Attribution 4.0 International License (http:// creativecommons.org/licenses/by/4.0/), which permits unrestricted use, distribution, and reproduction in any medium, provided you give appropriate credit to the original author(s) and the source, provide a link to the Creative Commons license, and indicate if changes were made.

\section{References}

Bain JM, Stubberfield C, Gow NAR (2001) Ura-status-dependent adhesion of Candida albicans mutants. FEMS Microbiol Lett 204:323-328

Bensaci MF, Gurnev PA, Bezrukov SM, Takemoto JY (2011) Fungicidal activities and mechanisms of action of Pseudomonas syringae pv. syringae Lipodepsipeptide Syringopeptins 22A and 25A. Front Microbiol 2:216. doi:10. 3389/fmicb.2011.00216

Bizerra FC, Melo ASA, Katchburian E et al (2011) Changes in cell wall synthesis and ultrastructure during paradoxical growth effect of caspofungin on four different Candida species. Antimicrob Agents Chemother 55:302-310. doi:10.1128/AAC.00633-10

Chaffin WL (2008) Candida albicans cell wall proteins. Microb Mol Biol Rev 72:495-544. doi:10.1128/MMBR.00032-07

Coimbra CD, Rufino RD, Luna JM, Sarubbo LA (2009) Studies of the cell surface properties of Candida species and relation to the production of biosurfactants for environmental applications. Curr Microbiol 58:245-251. doi:10.1007/ s00284-008-9315-5

Fonzi WA, Irwin MY (1993) Isogenic strain construction and gene mapping in Candida albicans. Genetics 134:717-728

Gillum AM, Tsay EYH, Kirsch DR (1984) Isolation of the Candida albicans gene for orotidine- 5 '-phosphate decarboxylase by complementation of $\mathrm{S}$. cerevisiae ura3 and E. coli pyrF mutations. Mol Gen Genet 198:179-182

Glee PM, Cutler JIME, Benson EE et al (2001) Inhibition of hydrophobic protein-mediated Candida albicans attachment to endothelial cells during physiologic shear flow reference or source. Infect Immun 69:2815-2820. doi:10. 1128/IAI.69.5.2815

Gow NAR, Bates S, Brown AJP et al (1999) Candida cell wall mannosylation: importance in host-fungus interaction and potential as a target for the development of antifungal drugs. Biochem Soc Trans 27:512-516

Grangemard I, Wallach J, Maget-Dana R, Peypoux F (2001) Lichenysin. A more efficient cation chelator than surfactin. Appl Biochem Biotechnol 90:199-210

Hazen KC (2004) Relationship between expression of cell surface hydrophobicity protein 1 (CSH1p) and surface hydrophobicity properties of Candida dubliniensis. Curr Microbiol 48:447-451. doi:10.1007/s00284-003-4223-1

Hazen KC, Wu JG, Masuoka J (2001) Comparison of the hydrophobic properties of Candida albicans and Candida dubliniensis. Infect Immun 69:779-786. doi:10.1128/IAI. 69.2.779
Hobden C, Teevan C, Jones L, Shea PO (1995) Hydrophobic properties of the cell surface of Candida albicans: a role in aggregation. Microbiology 141:1875-1881

Janek T, Łukaszewicz M, Rezanka T, Krasowska A (2010) Isolation and characterization of two new lipopeptide biosurfactants produced by Pseudomonas fluorescens BD5 isolated from water from the Arctic Archipelago of Svalbard. Bioresour Technol 101:6118-6123. doi:10.1016/j. biortech.2010.02.109

Janek T, Łukaszewicz M, Krasowska A (2012) Antiadhesive activity of the biosurfactant pseudofactin II secreted by the Arctic bacterium Pseudomonas fluorescens BD5. BMC Microbiol 12:24. doi:10.1186/1471-2180-12-24

Kaczorek E, Chrzanowski L, Pijanowska A, Olszanowski A (2008) Yeast and bacteria cell hydrophobicity and hydrocarbon biodegradation in the presence of natural surfactants: rhamnolipides and saponins. Bioresour Technol 99:4285-4291. doi:10.1016/j.biortech.2007.08.049

Kaczorek E, Sałek K, Guzik U, Dudzińska-Bajorek B (2013) Cell surface properties and fatty acids composition of Stenotrophomonas maltophilia under the influence of hydrophobic compounds and surfactants. N Biotechnol 30:173-182. doi:10.1016/j.nbt.2012.09.003

Klis FM, De Jong M, Brul S, De Groot PWJ (2007) Extraction of cell surface-associated proteins from living yeast cells. Yeast 24:253-258. doi:10.1002/yea

Krasowska A, Sigler K (2014) How microorganisms use hydrophobicity and what does this mean for human needs? Front Cell Infect Microbiol 4:112. doi:10.3389/fcimb. 2014.00112

Makovitzki A, Avrahami D, Shai Y (2006) Ultrashort antibacterial and antifungal lipopeptides. Proc Natl Acad Sci U S A 103:15997-16002. doi:10.1073/pnas.0606129103

Masuoka J, Hazen KC (1997) Cell wall protein mannosylation determines Candida albicans cell surface hydrophobicity. Microbiology 143:3015-3021

Masuoka J, Hazen KC (1999) Differences in the acid-labile component of Candida albicans mannan from hydrophobic and hydrophilic yeast cells. Glycobiology 9:1281-1286

McCourtie J, Douglas LJ (1981) Relationship between cell surface composition of Candida albicans and adherence to acrylic after growth on different carbon sources. Infect Immun 32:1234-1241

Mukherjee P, Chandra J (2003) Mechanism of fluconazole resistance in Candida albicans biofilms: phase-specific role of efflux pumps and membrane sterols. Infect Immun 71:4333-4340. doi:10.1128/IAI.71.8.4333

Neu TR (1996) Significance of bacterial surface-active compounds in interaction of bacteria with interfaces. Microbiol Rev 60:151-166

Peypoux F, Bonmatin JM, Wallach J (1999) Recent trends in the biochemistry of surfactin. Appl Microbiol Biotechnol 51:553-563

Pitarch A, Sanchez M, Nombela C, Gil C (2002) Sequential fractionation and two-dimensional gel analysis unravels the complexity of the dimorphic fungus Candida albicans cell wall proteome. Mol Cell Proteomics 1:967-982. doi:10.1074/mcp.M200062-MCP200

Pueyo MT, Bloch C, Carmona-Ribeiro AM, di Mascio P (2009) Lipopeptides produced by a soil Bacillus megaterium 
strain. Microb Ecol 57:367-378. doi:10.1007/s00248-0089464-x

Raaijmakers JM, De Bruijn I, Nybroe O, Ongena M (2010) Natural functions of lipopeptides from Bacillus and Pseudomonas: more than surfactants and antibiotics. FEMS Microbiol Rev 34:1037-1062. doi:10.1111/j.1574-6976. 2010.00221.x

Sanglard D, Ischer F, Monod M, Bille J (1997) Cloning of Candida albicans genes conferring resistance to azole antifungal agents: characterization of CDR2, a new multidrug ABC transporter gene. Microbiology 143:405-416

Singh N, Pemmaraju SC, Pruthi PA et al (2013) Candida biofilm disrupting ability of di-rhamnolipid (RL-2) produced from Pseudomonas aeruginosa DSVP20. Appl Biochem Biotechnol 169:2374-2391. doi:10.1007/s12010-013-0149-7
Sotirova AV, Spasova DI, Galabova DN et al (2008) Rhamnolipid-biosurfactant permeabilizing effects on gram-positive and gram-negative bacterial strains. Curr Microbiol 56:639-644. doi:10.1007/s00284-008-9139-3

Verstrepen KJ, Klis FM (2006) Flocculation, adhesion and biofilm formation in yeasts. Mol Microbiol 60:5-15. doi:10.1111/j.1365-2958.2006.05072.x

Zhong H, Zeng GM, Liu JX et al (2008) Adsorption of monorhamnolipid and dirhamnolipid on two Pseudomonas aeruginosa strains and the effect on cell surface hydrophobicity. Appl Microbiol Biotechnol 79:671-677. doi:10.1007/s00253-008-1461-y 